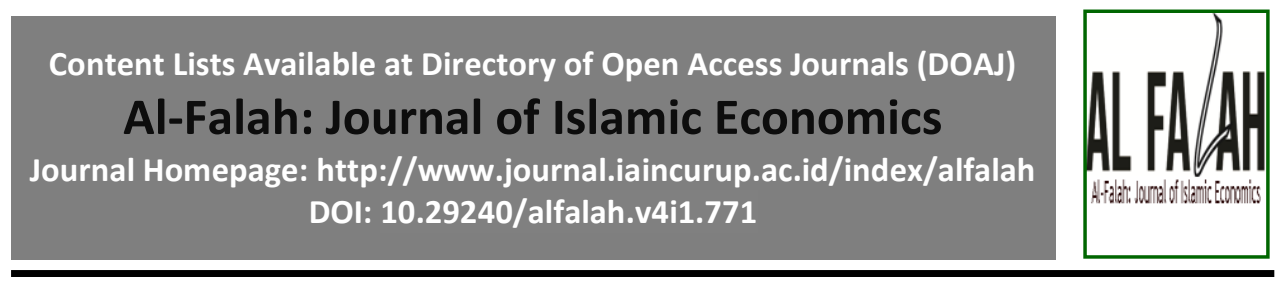

\title{
Boosting The Welfare of Business Community: Implementing The Model of Islamic Micro Bank of Waqf in Pesantren
}

\author{
Marlya Fatira AKa ${ }^{*}$, Anriza Witi Nasution ${ }^{b}$ \\ a State Polytecnics of Medan, Indonesia \\ b State Polytecnics of Medan, Indonesia \\ *E-mail Address: fatira.ak@gmail.com
}

\begin{tabular}{l}
\hline ARTICLE INFO \\
\hline Article History: \\
Received 08-03-2019 \\
Revised 29-03-2019 \\
Accepted 16-05-2019 \\
\hline Keywords: \\
Welfare \\
Community Business \\
Micro Waqf Bank \\
Islamic Boarding School
\end{tabular}

Paper Type:

Research Paper

\begin{abstract}
$\underline{\text { ABSTRACT }}$
Purpose: The Paper is to study the Ability of micro waqf bank (BWM) in boosting The Welfare of Community Business Group at the Islamic Boarding School.

Design/Method/Approach : This study uses a descriptive analysis. It intensively Implemented a qualitative approach to obtain information and collected the data needed through conducting interviews directly with informants. Both Observation and library study also applied to extent the secondary data. These methods were conducted to look at the Micro waqf bank model in Islamic boarding schools in Java of whether is able in boosting The Welfare of Business Community around the Islamic boarding school.

Findings: The Islamic Boarding School-based Micro-Waqf Bank. Model in Java that was applied for community empowerment was carried out a productive financing models in order to make communities able to manage the business-with a financing value of 1-3 million rupiah, within a maximum period of 1 year and payment per week with a maximum margin value equal to 3\%. Building a Micro Waqf Bank in the Pesantren can perform through collecting a set of data of cooperative business entities in boarding schools, obtaining LKMS business licenses, obtaining funding for the establishment of $B M W$, selecting financing customers, and conducting training for selected customers of BWM financing.

Originality/Values: The main contribution of this study concern on filling the gap of how the micro bank of waqf efectivelly boost the welfare the bussiness

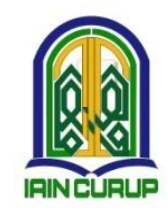

Al-Falab: Journal of Islamic Economics Vol. 4 No. 1 , 2019 (C) IAIN Curup
\end{abstract} community in pesantren.

\section{INTRODUCTION}

Waqf is one of the Islamic financial instruments that serve to guarantee the formation of public welfare. Endowments Management is carried out by the Islamic Public Finance Institution known as the ZISWAF Institute (Zakah, Infaq, Sadaqah, and Endowments). Nowadays the condition of waqf management in Indonesia increasingly right, seen serve attention from the Indonesian Waqf Agency (BWI) and 
the government of President Joko Widodo to support the success of waqf management to achieve community welfare.

Waqf in Indonesia has great potential in helping the development of the national economy. Waqf in productive form is expected to solve the problems of the poor in Indonesia. Through productive waqf, endowments evolved from social, religious activities, into economic activities such as building roads, bridges, working on agricultural land, plantations, and trade. This situation will form productive community empowerment, and the community's economy will be formed from the bottom so that it ultimately supports a healthy national economy. A significant potential to do, considering that based on data from the Indonesian Waqf Agency (BWI), it is known that waqf potential in Indonesia consists of waqf land potential above Rp. 370 trillion, potential cash waqf of One hundred eighty trillion Rupiah and potential untapped land that can reach Rp 2,000 trillion.

The enormous potential of waqf assets in Indonesia is spread in various parts of Indonesia and can collect by various layers of society including Islamic boarding schools. A large number of Islamic boarding schools, which are more than 28 thousand Islamic boarding schools spread throughout the territory of Indonesia with the majority of villages, presents an excellent opportunity for the government to overcome the problem of poverty in the village. This was known as the community empowerment movement through Islamic boarding schools.

The effort to empower rural communities through Islamic boarding schools was realized by the presence of 20 micro waqf banks in Islamic boarding schools in Java, precisely in Cirebon, Bandung, Ciamis, Serang, Lebak, Purwokerto, Cilacap, Kudus, Klaten, Yogyakarta, Surabaya, Jombang and Kediri. The Micro Waqf Bank business permit in the Islamic boarding school environment was issued by the Financial Services Authority (OJK) in March 2018. OJK through its leader Wimboh Santoso was hoping for the establishment of sustainable sharia economic development and could improve people's lives, and be able to reduce inequality and poverty. This effort is carried out by expanding the provision of access to public finance in the form of capital or financing for people who un bankable with formal financial institutions, especially in Islamic boarding schools.

BWM inaugurated by President Joko Widodo and OJK in the pesantren environment in the form of a Sharia Micro Finance Institution (LKMS). As of the beginning of March 2018, of the 20 Micro Waqf Banks formed, funding has distributed to 2,784 customers with a total financing value of $\mathrm{Rp} 2.45$ billion. The financing scheme through BWM is in the form of unsecured financing with a maximum value of Rp 3 million and profit sharing margin equal to 3 percent ${ }^{1}$.

In carrying out its operational activities, BWM is not permitted to take deposits from the community because it has a focus on community empowerment through financing along with business assistance, training and financing patterns made per group or joint responsibility. They are noting the excellent potential for the development of the boarding school-based BMW, the OJK targets to form a minimum

1 Makhrus Restu Frida Utami, "Peran Filantropi Islam Dalam Pemberdayaan Masyarakat Di Kabupaten Banyumas," in Proceeding Hasil Seminar Nasional Hasil-Hasil Penelitian Dan Pengabdian (Seminar Riset LPPM Universitas Muhammadiyah Purwokerto, Purwokerto: LPPM Universitas Muhammadiyah Purwokerto, 2015). 
of 50 BMW-based Islamic boarding schools in various regions including the Sumatra region. Currently, 20 BMWs have been formed in the Java region, following for the Sumatra region. This opportunity is of course very well utilized by the North Sumatra area (SUMUT) which has 220 Islamic boarding schools (Medna 2017). Noting the number of Islamic boarding schools in North Sumatra, at least 5 BMW projects based on Islamic boarding schools in North Sumatra can realized. Learning from the success of BWM that has formed in the Java region, known that to establish a BMW requires a minimum fund of 4 billion Rupiah to encourage a program of financial inclusion. So far, the waqf bank's funding sources have come from the National Amil Zakat Institution (Laznas) with a value of more than IDR 4 billion and other donors from the pesantren and the general public. If North Sumatra wishes to establish 5 BMW projects, ${ }^{2}$ then funds of around IDR 20 billion are needed. This quite potential considering that North Sumatra has the 4th largest waqf assets for all of Indonesia.

It is expected that from this study a waqf bank model can be found that has been applied in Central Java, especially the Klaten area, Yogyakarta and Kudus as the area that became the first pilot of the Waqf Bank since it was repaid in 2017. Through the approach of socio-economic theories it is expected to be able to reveal community empowerment programs that have been applied to 20 BMWs in Java, so that they can be used as input and consideration for BWI parties, Islamic Boarding Schools, Baznas, to work together To succeed the government program empowers the community to alleviate poverty by building an economy based on the pesantren economy through the support of the Micro Waqf Bank.

The presence of a Micro Waqf Bank in Java as a Pilot Project phase I since October 2017 in some areas in Java has given a lot of good to the people around pesantren where micro waqf banks are established so as to alleviate poverty. However, until now the mechanism and work program of BWM carried out in Java have not been published to other pesantren in Indonesia, including North Sumatra, which have the potential to educate micro waqf banks. Noting this, it is important to do this research. In focusing the efforts to solve the problem, the research questions are determined as follows: How is the Model Islamic Boarding School based Islamic Boarding School in the Java Region applied for community empowerment?

\section{BACKGROUND THEORY}

The study considers various theories. First, Micro Waqf Bank: according to Wimboh Santoso (www.republika.co.id, 9 March 2018), Micro Waqf (BWM) bank is a form of Islamic microfinance institution that is licensed and supervised by the Financial Services Authority (OJK) to provide access to capital or financing for the community in particular for middle and small communities. The purpose of establishing a Micro Waqf Bank is to support the sustainable sharia economic development, improve the living standard of the community through the provision of financing along with business assistance, and able to reduce inequality and poverty, by providing financial access and providing business assistance to communities and small

2 Tholhah Hasan, "Sumut Luncurkan Wakaf Uang," January 21, 2013, https://bwi.or.id/index.php/ar/publikasi/ berita-mainmenu-109/906-sumut-luncurkan-wakafuang.html. 
and medium micro enterprises. The existence of BWM is also a major commitment of the OJK together with the government and amil zakat institutions (LAZ) to continue to expand the provision of access to public finance, especially for the middle and small communities. OJK hopes BWM can provide capital access for people who are not yet connected with formal financial institutions.

Second, Microfinance Institutions: Microfinance Institutions (MFIs) are specialized financial institutions established to provide business development and community empowerment services, either through loans or financing in micro-scale businesses to members and the community, deposit management, and the provision of business development consulting services that are not solely seeking profit.

Third, Business Activities of MFIs: Following are the MFI's business activities-the MFI's business activities include business development and community empowerment services, either through loans or financing in micro-scale businesses to members and the community, deposit management, and the provision of business development consulting services, Business activities that can be carried out conventionally or based on Sharia Principles, MFIs can conduct fee-based activities insofar as they do not conflict with statutory provisions in the financial services sector.

Fourth, Purpose of the MFI: following are the MFI's Objectives--increasing access to micro-scale funding for the community; Helping to increase economic empowerment and community productivity; and help increase the income and welfare of the community, especially the poor or low income people. Fifth, Obligation to Obtain MFI Business License--next is the Business License of the MFI. Institutions that will run an MFI business after the enactment of Law Number 1 of 2013 concerning Microfinance Institutions must obtain an MFI business license, Applications for business licenses as MFIs are submitted to the Regional Office; OJK Office; or MFI Directorate according to the MFI's place of domicile.

Sixth, Form of MFI Legal Entity: The following are the forms of the MFI's business entity-- cooperative or, Limited Liability Companies (shares of at least 60 percent owned by the district ; city government or village, or kelurahan business entities, the remaining PT share ownership can be owned by Indonesian citizens or cooperatives with the most ownership of Indonesian citizens at 20 percent). Seventh, Philanthropy, Endowments and Islamic Boarding Schools: Philanthropy comes from two Greek words, namely philos and anthropo which means love of people, love fellow humans. ${ }^{3}$ Judging from these two words, philanthropy is more related to human efforts to show love for others through various efforts made. But in its development, philanthropy is more associated with the process of sharing private resources for public benefits. Private resources here are not always meant by money, but other forms of resources, such as goods, thoughts and energy. From the description of the definition of philanthropy, it can be concluded that philanthropic activities contain the meaning of humanity, solidarity, subsidiary, non profi orientation, and voluntarism.

However, it is necessary to examine philanthropic activities and mobilization of resources in the context of the institution of social religious boarding schools that are not yet large enough. One of the philanthropic models offered in Islam is the waqf instrument. In fact, the existence of waqf, especially land waqf, in the archipelago has been carried out since the birth of Muslim communities. Waqf institutions appear

${ }^{3}$ Kim Klein, Fundraising for Social Change (Oakland California: Chardon Press, 2001), 5. 
together with the birth of Muslim societies, as a community generally requires facilities for worship and education to ensure its continuity as the forerunner of Islamic boarding schools. These facilities can be fulfilled by means of waqf, both in the form of land, building materials, and energy donations.

Waqf itself means holding back property that can be taken advantage of without being destroyed instantly and for corrupt use, and intended to obtain the pleasure of Allah SWT. Or in other words, waqf is holding back the origin and flowing the results. In this way, waqf assets can be used for public and public benefit in a sustainable manner without losing the original assets. Waqf is known to function to empower the economy of the people. The instrument of waqf is so great for the Muslim community, both past, present and future, as a model and pattern for improving the welfare of the people. In the Indonesian context, it is needed such as the formulation of new waqf conceptions, productive management of waqf, Nazhir coaching, legislation that supports it, and joint commitment between Nazhir, the government and society to develop waqf productively.

At this point, Nazhir's position, the party that receives the waqf property from wakif to be managed and developed according to its designation, is very decisive. Ideally, Nazhir is not only a person or legal entity that has religious abilities but also has expertise in seeing productive business opportunities so that waqf property truly develops optimally. It appears that in the representation, Nazhir plays a very important role. In order for the treasure to function properly and can continue continuously, the property must be maintained, maintained, and if possible developed. In this context, it is very important to link the development activities of waqf with pesantren institutions. The role of Nazar Islamic Boarding School waqf is really needed. As is known, Islamic boarding schools are a social educational institution for Muslim communities that have distinctive patterns and management characteristics and prioritize independence. Islamic boarding schools as social institutions also have a noble vision in order to enlighten the religious life of the wider community and develop a moderate personality to give blessings to their environment.

Fundraising (raising the source of funds, or power) waqf of the pesantren itself is interpreted as an activity to raise funds and other resources in the form of waqf from the community (individuals, institutions, companies and the government) that will used to finance the program and operational activities of the pesantren which ultimately is to achieve the mission and purpose of the pesantren. ${ }^{4}$ From this simple understanding, the aim of waqf boarding fundraising is at least five main objectives, namely: raising funds, or endowments, gathering wakif, gathering volunteers and supporters, building the image of pesantren institutions and satisfying time. Islamic boarding schools and also try to provide alternative models for the development of fundraising, or endowments so the boarding school institution can strengthen its independence in carrying out a vision to enlighten people's lives.

Micro business at Islamic boarding schools succeed to created welfare society. Since 14th century, pesantren has a function as an institution of da'wah, educational institutions and cadre formation and the center of the ummah's struggle against invaders; then in the 1980s, through the Center for Islamic Boarding Schools and Community Development (P3M), the world of Islamic boarding schools gained new

\footnotetext{
${ }^{4}$ Hendra Sutisna, Fundraising Database (Jakarta: Primedia, 2006)., p. 15
} 
functions, namely as a center for community empowerment. So many Islamic boarding schools are used as trials for community empowerment programs. We know several Islamic boarding schools, for example the Darul Falah Islamic Boarding School, Pabelan Magelang Islamic Boarding School, Kajen Pati Islamic Boarding School, Langan Tuban Islamic Boarding School, An-Nuqayah Madura Islamic Boarding School, etc. which are used as centers for community empowerment. The hustle and bustle of community empowerment then became extraordinary in the world of boarding schools. Then in the era of the 2000s, pesantren gained additional new functions, namely as a center for populist economic development. Then came the pesantren with its characteristic of developing cooperatives, such as the Sidogiri boarding school. This indicates that the world of pesantren is actually not empty of continuous innovation. And this also indicates that the world of boarding schools has a very high response to changing times. So, actually pesantren are social and educational institutions that can become pillars of community empowerment.

Broadly speaking, there are two strategic roles of Islamic boarding schools in sharia:

First is the role of scientific development and socialization of Islamic economics to the community. This is because Islamic boarding schools are recognized as institutions that are legitimate ulama and dai in the community. Islamic boarding school product scholars have the potential to become Islamic economic scholars who are indispensable as Sharia Supervisory Board (DPS) for Islamic Financial Institutions (LKS) whose function is to supervise and maintain LKS activities and programs in accordance with sharia. Besides that they can also act as mouthpieces for sharia economic socialization in the community, because they are role models and their voices are more heard than the ulama and dai products of non-pesantren institutions. Their other strengths are that they have better mastery of muamalah figh, so that they have the ability to explain the Shari'ah economy to the community better.

Second is the role of realizing the real practice laboratory of sharia economic theory in economic activity. this role is also very strategic, considering the community sees pesantren as examples and role models in their daily activities. If pesantren develop their potential in Islamic economics and succeed, of course it will be followed by the community. God willing, they will be busy migrating from the capitalist economic system to an Islamic economy that is free from usury, maysir, gharar, risywah, dlalim, sale and purchase of illicit goods and various other forms of disobedience. Conversely, if passive and apathetic pesantren certainly influence the community, especially if they still interact with the conventional economy.

In order to continue its existence in the business world, Islamic boarding schools must innovate in developing their products. If you only rely on traditional markets that are owned, the development will tend to be stagnant. The first step is to streamline the production factors that are owned which then develop product and labor diversification. Thus it will bring economic efficiency. While economic efficiency refers to the output value of the input, or the value of resources (production factors) that are used to produce the output. The measurement of economic efficiency requires values to be placed on commodities. In welfare analysis, the value placed (as a unit of calculation or measure) on the commodity is the values given by the perfect market. Italian economy, Dilfredo Pareto, has specified a condition or condition for the creation of efficient or optimal resource allocation, which is then known as pareto 
condition (pareto condition). Pareto condition definition is an allocation of goods in such a way that if compared to other allocations, the allocation will not harm any party and one party will definitely benefit. Pareto conditions can also be defined as a situation where some or all parties or individuals will no longer be able to benefit from voluntary exchanges. This is the economic role of boarding schools as producers, we further estimate the role of boarding schools in providing outputs of production goods.

The boarding school was founded by KH Drs Muchtar Adam on January 18, 1981 and Darussalam Gontor Islamic Boarding School, Ponorogo. Islamic boarding schools as consumption institutions are shown from the number of production goods absorbed by Islamic boarding schools both by students as students and pesantren as educational institutions. It can be added if the pesantren has a production business, then the raw materials for this production business will also absorb not less production goods. Micro, Small and Medium Enterprises (MSMEs) can be a force inside poverty alleviation, job creation and becoming a force in increasing family income. Money waqf offers opportunities to help MSME business groups and empower Micro, Small and Medium Enterprises to increase MSME income. 2.5 Empowerment of Islamic School Potential The economic development of the pesantren is intended to support the independence of the pesantren as well as the impression that the santri is only good at reciting and praying can be answered with concrete evidence. Independence of life in the economic field is basically the implementation of Islamic teachings that are studied in Islamic boarding schools. Optimizing the development of the economic potential of the pesantren can be carried out with severa

\section{METHOD}

The method used in this study is a qualitative descriptive research method. Descriptive research is research that deals with the question of the existence of independent variables, both only on one or more variables and does not make comparisons or find relationships between one variable and another. Literature studies are used more in this study to describe the problem. This study uses a qualitative approach because it interprets, highlights and explains a unique phenomenon and this research is difficult to quantify by quantitative research, because it deals with understanding people's experiences related to the phenomena that occur. Moleong dalam defines qualitative research as follows: Qualitative research is research that intends to understand the phenomenon of what is experienced by the subject of research such as behavior, perception, motivation, action, etc., holistically by describing in the form of words and language, in a special natural context by utilizing various natural methods.

\section{Research Model}

The Micro Waqf Bank model issued by the Financial Services Authority obvious can understand based on the below figure : 


\section{Figure 1.}

The Micro Waqf Bank model

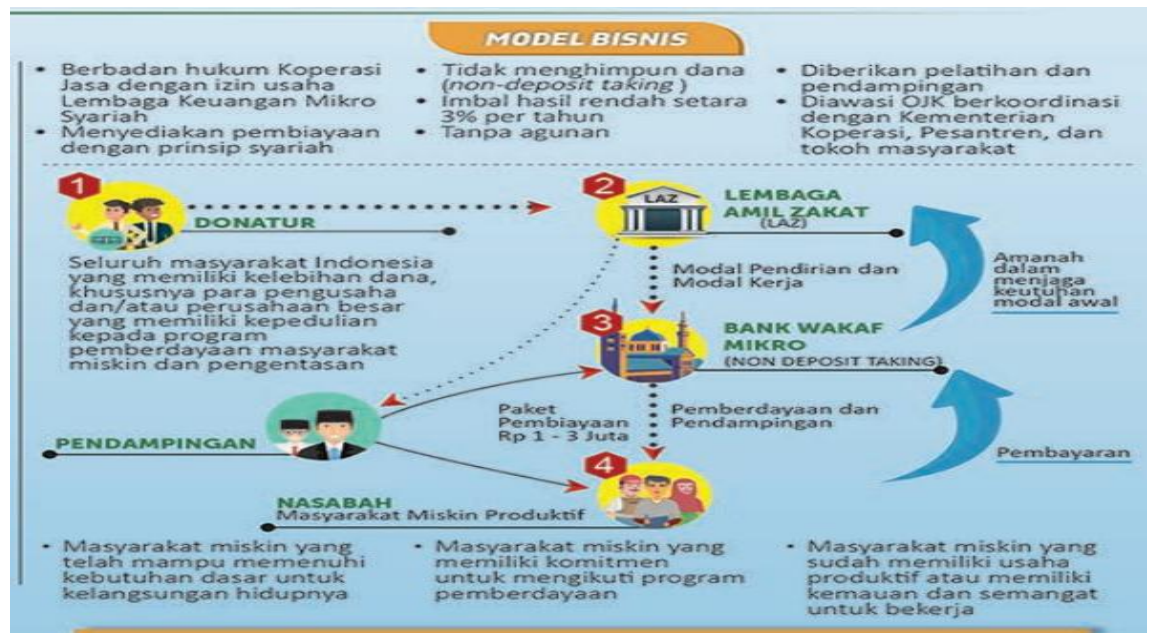

Through the Financial Services Authority there are various benefits of Micro Waqf Banks, namely: 1) Business Training and Assistance, 2) Increase literacy and financial inclusion, 3) Reducing inequality and poverty, 4) Business Capital Financing, 5) Apply the system to pick up the ball, 6) Avoid moneylenders, 7) No interest, 8) Unsecured Financing, 9) 3\% Margin Sharing System. On other hands, in this study the micro waqf bank model to be explored, it can be explained bellow:

Figure 2.

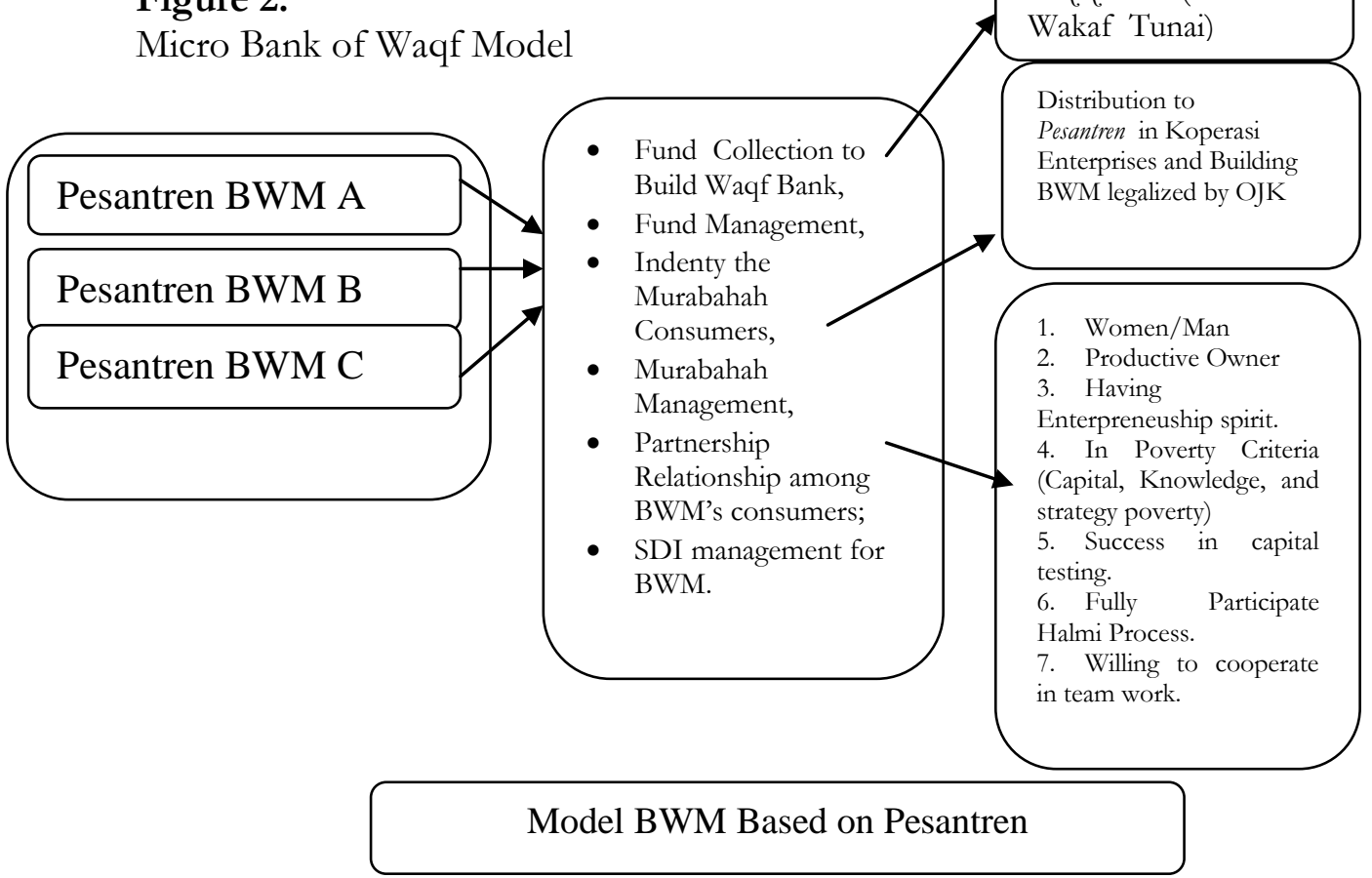




\section{FINDINGS AND DISCUSSION}

Based on the results of data collection carried out it is known that BWM is in Purwekerto. That the funding provided by BWM is given to productive customers with the criteria of being poor people who have been able to meet their daily needs, already have a business but have not developed, but have the willingness to try. This was conveyed by the Head of the Islamic Banking Department of the Financial Services Authority (OJK) Ahmad Soekro Tratmono on Friday (May 6, 2018) during the Mass Media Training and Gathering in Purwokerto.

Furthermore, in the initial process, prospective BWM customers will take part in the selection of prospective customers through five days of mandatory group training (PWK) with material on discipline, cohesiveness, solidarity and courage to try. After that, a group of customers who have passed PWK will be selected and named the Indonesian Pesantren (KUMPI) Surrounding Community Business Group consisting of five people. Then a group called Halaqoh Mingguan (HALMI) was formed which consisted of 3-5 groups. In each group consists of 4-5 people, then educated five days. Educated by solidarity, commitment to try and togetherness.

In the early stages of this BWM customer group activity, a meeting was held with disbursement of funds. Next is a weekly HALMI meeting with weekly installment payment activities, material delivery for example business development and household economics.

The value of the disbursement of funds provided starts with a value ranging from Rp1,000,000-3,000,000. As a preliminary and trial stage, the majority of customers get a loan of Rp. 1 million. For some customers who get a loan of IDR 3,000,000, an analysis by the BWM manager will first be carried out.

Providing business capital by BWM is given with a maximum margin of $3 \%$ and without collateral. The loan period is an average of a maximum of 1 year by way of margin or installment payments every week. This situation makes the BWM model successful in saving the productive poor from activities dependent on loan sharks. Where before the community prioritized moneylenders by applying for loans to moneylenders with small value loans and paying interest at d.d. $50 \%$ per day. For example, borrowing IDR 100,000 and returning IDR 150,000 with door to door payments. The presence of BWM also serves as a customer for customer business incubators so that they can prepare customers who were non-bankable to become bankable.

\section{Building a Micro Waqf Bank}

Building a micro waqf bank can be done with the initial stages of obtaining donors. Given that BWM is a sharia microfinance institution initiated by OJK to channel loans to ultra micro businesses. So the initial funding for establishing BWM was through personal and corporate donations collected by LAZNAS. donations collected at LAZNAS at the initial stage reached Rp. 4 billion. Of these funds, Rp 3 billion is locked in the form of deposits at Bank Mandiri Syariah (BSM). Then, around Rp. 1 billion is channeled to business actors as a revolving fund.

Considering that the fund obtained is a revolving fund and it is necessary to ensure the sustainability of the availability of funds, not all collected funds are channeled to customers through BWM, but most are invested in Islamic deposits, 
considering that the deposit return products are stable. From the yield on deposits it is also used for BWM operating costs. In an effort to increase funding sources, donations can be received from anyone who donors, not necessarily Muslims. BWM resources can also come from non-Muslims. Then the funds submitted were of a non-returnable nature because it was a form of donation for BWM business development. In establishing a Micro Waqf Bank, pesantren must first have a cooperative. The form of the BWM Business Entity from the Cooperative then obtains a business permit from the OJK in the form of LKMS. So this shows that BWM is not a banking institution, but LKMS as part of the non-bank financial industry (IKNB). Supervision of BWM as IKNB is under OJK. This BWM does not perform waqf functions. The naming of BWM is due to the existence of BWM operating in the pesantren area. The establishment of this BWM is in an effort to bring banking institutions closer to carrying out financial inclusion functions. So far, financial inclusion functions cannot be carried out by conventional banks or Islamic banks because banks have strict rules in their operational activities.

BWM is a cooperative business entity and licensed by LKMS, the micro waqf bank has its own provisions. Micro waqf banks cannot function as banks as deposit recipients, but can channel financing. Other provisions of micro waqf banks are group based, yields are low or only $3 \%$ per year and without collateral. The presence of micro waqf banks in Indonesia originated from the current poverty and inequality, the number of poor people in Indonesia was 26.6 million or around $10.12 \%$. This situation is supported by the high inequality, which is at the level of 0.39 . At present almost all regions in Indonesia tend to have a poverty rate of $12-28 \%$ or above the national average. Therefore, an active role is needed from all elements of society, one of which is through the economic empowerment of the people who also carry out the assistance function. Currently the choice of community elements that have a strategic function in assisting to encourage the economy of the community is Islamic boarding schools. With the potential of 28,194 pesantren, pesantren have great potential to empower people and play a role in eroding economic disparities and alleviating poverty.

The economic development and empowerment model of MSMEs is an effort to improve the socio-economic outline of this MSME business group in its implementation must be carried out in accordance with the objective conditions and socio-cultural and economic characteristics that will be transformed. With a reading of accurate social reality, then endowments of money as an instrument of empowerment the people's economy will be right on target so that the principles of Islamic economics to build a people's economic balance can truly be realized. According to Soetrisno (2013), waqf funds can empower small businesses still dominant in this country $(99.88 \%)$. Endowments collected can be channeled to the community, including groups of MSME entrepreneurs with profit sharing systems. The benefits of money waqf investment are used for the empowerment program (enpoweenpowerment) of the poor so that capital can be used sustainably, even if it allows capital to be rotated to other people who also need it, either in order to strengthen distributive capacity or as an initial capital to start a business (capacity productive).

To measure the influence raised from the management of waqf money can be seen from the indicators in the form of real sector movements and economic empowerment of the community. According to MA Mannan, one of the indicators of the effectiveness of money waqf is income redistribution. Expenditure of funds 
obtained from the results of waqf management plays an important role in each income redistribution vertically. Expenditures of waqf funds must be coordinated so that the effect of income redistribution can be in favor of the poor, namely by providing important services and infrastructure for the poor, such as education facilities. Based on what has been proven by MA Mannandi SIBL, with effective waqf management, horizontal income redistribution has occurred significantly from one income group to another income group (Mannan, 1999) Like zakat, According to Ahmed (2004), waqf can have an influence towards micro economic activities, has a positive contribution in order to improve the welfare of the ummah. The benefits felt by the community through investment in waqf funds are quite large. People get financing capital and share the results. They also receive guidance in the form of business, as well as in the mental and spiritual form of their community groups to do business and in a lawful way. For example, those who have done Tube Wakaf Indonesia (TWI) me Through LPEU Insan Kamil, the TWI fostered partners in Palembang, the Independent Community in Jakarta and Bogor, and the Livestock Village received endowments to develop their businesses.

No less important is the mental and moral education of the community. Where people in business groups are nurtured to have entrepreneurial spirit so that those who have previously sought life from a way that is not lawful, can abandon the habit by seeking a lawful business. Likewise, the assisted community is given a kind of spiritual encouragement in the form of encouragement to work in halal sectors. In addition, they are also motivated to set aside some of their rams to be represented and other motivations that invite people to goodness.

This money waqf investment program into the real sector is a form of poverty alleviation program. In addition, the UMKM business group selection system will certainly make it easier to monitor businesses so that business risks can be minimized. In addition to this, the system for screening community groups, the benefits of waqf can certainly be enjoyed by many people. How many MSME business groups can be provided with capital assistance and how many poor people can enjoy the business results of money waqf investments. The money waqf as invested, proved to give an opportunity to community for business development and economic empowerment. This means that waqf investment into the real sector has a positive effect on improving people's welfare as well as providing awareness the meaning of waqf itself.

According to Zarqa (2008), Professor at the Center for Research in Islamic Economics at King Abdul Aziz University, endowments have actually been known in society since classical times. Islam recognizes this noble tradition and places it as an eternal religion, so endowments thrive in Islamic society throughout history. Then put it as an important social service, especially in the construction of mosques, schools, hospitals, drinking water sources, and support for the poor. In its history, the substance of waqf money has actually appeared for a long time. In fact, in the study of classical jurisprudence along with the emergence of the idea of revitalizing figh mu'amalah in the perspective of maqashid sharia which leads to maslahah al-mursalah, it includes efforts to realize social welfare through the justice of income and wealth distribution. Thus there is no doubt that waqf provides many benefits for the life of society both socially and economically. From a social perspective, waqf can be used as a means to reduce poverty, control and harmony in social life, and increase social integration. So impressive is waqf, it can avoid the distance of the social class between 
the rich and the poor because people who are able to voluntarily share their wealth with the poor. Funds channeled to waqf management institutions are managed productively, then the management surplus is channeled to people who lack business capital. Thus, waqf productivity will trigger the creation of social justice which can immediately create support for the prosperity of the community. Here there is a form of income distribution from parties that have more income to those with low incomes. ${ }^{5}$ From the effect of income distribution it will clearly make equitable distribution of income if these wakafuang are truly managed effectively.

\section{CONCLUSION}

It can be sum up: First, improvement of economic human resources, both management and accounting. Training related to this must be held. Islamic boarding schools can collaborate with existing Community Economic Institutions (LPU) such as Islamic Banks, BMTs and BPRS as well as Non-Governmental Economic Development Institutions (LPESM) such as INKOPONTREN and PINBUK. Second, Improved management of economic institutions towards professional and sharia-based management. Poor management is a dominant factor for the development of the pesantren economy so far. Finally, Building networks, both with LPU, LPESM, alumni, the community and the government. The existing Pesantren Cooperative Network through its parent (INKOPONTREN) needs to be optimized in order to create a large number of potentials, both in business and marketing. []

\section{References:}

Republik Indonesia. 2010. Departemen Agama. Al Quran dan terjemah. Bandung: Hilal.

Ahmed, Habib. 2004. Role Zakeat and Awqaf in Poverty Alleviation. Jedah:Islamic Research and Training Institution. Islamic Development Bank.

Donna, Duddy Roesmara dan Mahmudi. 2007. The Dynamic Optimization of Cash Waqf Management: an Optimal Control Theory Approach, http:/ /psekp.ugm.ac.id.

Faishal, Achmad. 2012. Bentuk Bentuk Pengembangan Ekonomi Masyarakat di Pesantren (Studi Kasus atas Pengembangan ekonomi Masyarakat di PP. Annuqoyah Guluk-Guluk Sumenep Madura). Skripsi. Prodi. Sosiologi. FISIP UIN Syarif Hidayatullah Jakarta

Halim. 2005. Menggali Potensi Pondok Pesantren, dalam A.Halim et al, Manejemen Pesantren. Yogyakarta: Pustaka Pesantren.

Hasanah, Uswatun. 2003. Potret Filantropi Islam di Indonesia, dalam Idris Thaha (Edit), Berderma untuk semua: Wacana dan Praktek Filantropi Islam . Jakarta:PBB UIN Jakarta dan FF.

${ }^{5}$ Duddy Roesmara, "The Dynamic Optimization of Cash Waqf Management: An Optimal Control Theory Approach,” 2007, http://psekp.ugm.ac.id. 
Huda, Miftahul. 2013. Fundraising Wakaf dan Kemandirian Pesantren (Strategi Naz̧bir Wakaf Pesantren dalam Menggalang Sumberdaya Wakaf). Jurnal Inteligensia. Jawa Timur: IAIN Ponorogo.

Ismail SM dkk (ed). 2002. Dinamika Pesantren dan Madrasah. Yogyakarta: Pustaka Pelajar.

Klein, Kim. 2001. Fundraising for Social Change, Fourth Edition (Oakland California: Chardon Press)

Makhrus, dan Restu Frida Utami. 2015. Peran Filantropi Islam Dalam Pemberdayaan Masyarakat di Kabupaten Banyumas. Proceeding Hasil Seminar Nasional Hasil-Hasil Penelitian dan Pengabdian. LPPM Universitas Muhammadiyah Purwokerto.

Mannan, M.A. 1999. Cash Waqf Certificate Global Opportunity the Sosial Capital Market in 21st-Century Voluntary-Sektor Banking, Proceeding of the Third Harvard University Forum on Islamic Finance, Cambridge, Massachussets, Harvard University, 30 September-2 Oktober 1999.

Moleong, Lexy J. 2001. Metode Penelitian Kualitatif. Bandung: PT Remaja Rosdakarya.

Mardani. 2012. Fiqih Mu'amalah. Jakarta: Kencana Prenada Media Group.

Rozalinda. 2013. Peran Wakaf Dalam Pemberdayaan Ekonomi Perempuan. Kamis, 30 Mei 2013, http://bwi.or.id, akses 5 Juli 2013.

Sigit, Santoso. 2003. Pengantar Metodologi Penelitian Sosial Bisnis Manajemen. Yogyakarta: FE UST.

Sutisna, Hendra. 2006. Fundraising Database. (Jakarta: Primedia).

Yuli, Sri Budi Cantika. 2015. Optimalisasi Peran Wakaf Dalam Pemberdayaan Usaha Mikro, Kecil dan Menengah (UMKM). Jurnal Ekonomika-Bisnis. Vol. 6 No. 1. Januari 2015. Pascasarjana FEBI UNAIR. Surabaya.

Yulianti, Rahmani Timorita. 2008. Peran Lembaga Kenangan Publik Islam Dalam Pemberdayaan Ekonomim Masyarakat. Millah Jurnal Studi Agama Vol. VIII, No.1 Agustus 2008.

Tholhah Hasan, 21 Januari 2013 dalam https://bwi.or.id/index.php/ar/publikasi/ berita-mainmenu-109/906-sumut-luncurkan-wakaf-uang.html

Undang-Undang Nomor 1 Tahun 2013 tentang Lembaga Keuangan Mikro. http://www.ojk.go.id/id/kanal/iknb/Pages/Lembaga-Keuangan-Micro.aspx

Undang-Undang No. 41 tahun 2004 tentang Wakaf 
